\title{
Rice Grammaticality Judgment Task
}

National Cancer Institute

\section{Source}

National Cancer Institute. Rice Grammaticality Judgment Task. NCI Thesaurus. Code C160856.

An examiner-administered, 20-item grammar judgment task. The respondent listens to a series of prerecorded sentences (items) and indicates whether the sentence is grammatically correct. 